\title{
Study on stability of wheat germ oil and lipase activity of wheat germ during periodical storage
}

\author{
Mohamed G. Megahed \\ Fats and Oils Department, National Research Centre, Dokki, Cairo. Egypt \\ E-mail: dr_mgmegahed@hotmail.com
}

\begin{abstract}
The purpose of the present study was follow the influence of periodical storage (at room temperature, $25-30^{\circ} \mathrm{C}$ ), on the stability of oil including primary and secondary oxidation, total oxidation as well as conjugation. Color intensity at $430 \mathrm{~nm}$ of the oil samples was also evaluated to show changes of color during periodical storage. It was generally found peroxide value, $p$ anisidine, total oxidation, conjugated diene and conjugated triene gradually proportionally increase at storage periods of 1,2,3,4,5,6 and 7 days. The course of lipase inhibition was followed in wheat germ during periodical heat exposure, and it was found that the lipase activity was suppressed by exposure to temperature of $70^{\circ} \mathrm{C}$ for $30 \mathrm{~min}$. to keeping the majority of oil triglycerides in the intact condition. Samples of wheat germ oil were analyzed individually in triplicates, and the results were reported as mean $\pm S D$. Statistical significance of the differences between mean values was assessed by one-way ANOVA.
\end{abstract}

Keywords: Wheat germ oil, lipase activity, oil stability, total oxidation, total conjugation.

\section{INTRODUCTION}

Wheat germ is a by-product of the wheat milling industry. Germ constitutes about $2-3 \%$ of the wheat grain and can be separated in a fairly pure form from the grain during the milling process. Wheat germ contains a hydrolytic lipase and about $11 \%$ oil. (Sonntage,1979;Devin and Oscar,2006). Nevertheless, because of its unfavorable baking properties and susceptibility to oxidation, the germ is removed from the end endosperm during milling and is mainly used for fodder and for oil production (Appett, 1986).

Wheat germ oil is an excellent source of polyunsaturated fatty acids and vitamin $\mathrm{E}$. It is one of the richest natural sources of $\propto$-tocopherol, the type of tocopherol with the greatest vitamin $E$ activity. Wheat germ oil has been attributed to reduced plasma and liver cholesterol in animals, improved physical endurance, and delayed aging (Kahlon,1989;Tong and Lawrence,2001).

Although lipase activity in dormant seeds is generally quite low compared with germinating seeds, the hydrolysis of storage lipids is the most rapid chemical change that occurs in dormant wheat during storage. Lipid hydrolysis in whole grain products may lead to undesirable baking (Pomeranz,1980), sensory (Galliard and Gallagher,1988), and nutritional properties (Pomeranz,1992). Thus, many manufactures implement a heating step, which partially inactivates the lipase, during preparation of these products for commercial use (Devin and Oscar,2006). The heat treatment used to inactivate lipase may cause undesirable browning (Vetrimant and Haridas, 1990) and destruction of antioxidants (Mukherjee and Hills,1994;Lehtinen et al,2003); therefore, it is important to find the shortest heating time that will sufficiently inactivate the lipase (Devin and Oscar,2006).

This work was devoted to study the fatty acids composition as well as the effect of periodical storage at room temperature $\left(25^{\circ} \mathrm{C}-30^{\circ} \mathrm{C}\right)$ on the oil characteristics as well as primary and secondary oxidation. In addition, conjugation during periodical storage was studied.

The course of lipase inhibition was also studied in wheat germ during periodical exposure at temperature of $70^{\circ} \mathrm{C}$.

\section{MATERIALS AND METHODS}

Materials: Representative samples of wheat germ were obtained from Flour Land Company, $6^{\text {th }}$ October City, Egypt. The wheat germ collected directly after milling in polyethylene bags and kept at $5^{\circ} \mathrm{C}$. The other used chemicals were of high purity and technical grade (Merk, Germany and BDH, England). 


\section{METHODS}

Preparation of wheat germ samples for analysis: Wheat germ samples were stored at $5^{\circ} \mathrm{C}$ (control sample) and room temperature $\left(25-30^{\circ} \mathrm{C}\right)$. Another sample of wheat germ was heated to follow the influence of lipase during storage at $70^{\circ} \mathrm{C}$ for 15,30 and $60 \mathrm{~min}$. Wheat germ samples were ground (20$40 \mu \mathrm{m})$ and were subjected to hexane extraction.

Oil extraction: Soxhlet apparatus technique was utilized for oil extraction from dried and ground wheat germ using redistilled $n$-hexane according to the method of (A.O.C.S.,1996).

Chemical characteristics of oil: Chemical characteristics of the oil were conducted according to the method of (A.O.C.S.,1996).

Fatty acid composition: Wheat germ oil methyl esters were prepared according to (IUPAC,1987).Determination of wheat germ fatty acids composition was performed as described by (Mitruk,1984) using a Hewlet Packard HP 6890 gas chromatograph, operated under the following conditions:

Detector, flame ionization (FID); column, capillary, $30.0 \mathrm{~m} \times 530 \mu \mathrm{m}, 1.0 \mu \mathrm{m}$ thickness, polyethylene glycol phase (INNO Wax); $\mathrm{N}_{2}$ with flow rate, $15 \mathrm{ml}$ per min with average velocity $89 \mathrm{~cm} / \mathrm{s}(8.2 \mathrm{psi}) ; \mathrm{H}_{2}$ flow rate, $30 \mathrm{ml}$ per min; air flow rate, $300 \mathrm{ml}$ per min; split ratio, $8: 1$, split flow, $120 \mathrm{ml}$ per min; gas saver, $20 \mathrm{ml}$ per min. Detector temperature, $280^{\circ} \mathrm{C}$; column temperature, $240{ }^{\circ} \mathrm{C}$; injection temperature, $280^{\circ} \mathrm{C}$. Temperature programming starting from $100{ }^{\circ} \mathrm{C}$ to reach a maximum of $240{ }^{\circ} \mathrm{C}$ was used for eluting the fatty acid methyl esters. The identification of peaks was made as compared with chromatograms of saturated fatty acid methyl esters (Sigma, USA).

Table: 1. Fatty acids composition of wheat germ oil

\begin{tabular}{|c|c|c|c|c|c|c|c|}
\hline \multirow{2}{*}{ Extracted oil } & \multicolumn{9}{|c|}{ Fatty acids (\%) } \\
\cline { 2 - 8 } & \multicolumn{3}{|c|}{ Saturated fatty acids } & \multicolumn{5}{c|}{ Unsaturated fatty acids } \\
\cline { 2 - 8 } & $\mathrm{C}_{16: 0}$ & $\mathrm{C}_{18: 0}$ & $\mathrm{C}_{20: 0}$ & $\mathrm{C}_{18: 1}$ & $\mathrm{C}_{18: 2}$ & $\mathrm{C}_{18: 3}$ & $\mathrm{C}_{20: 1}$ \\
\hline Wheat germ oil & 16.22 & traces & 3.92 & 14.48 & 49.89 & 11.29 & 4.20 \\
\hline
\end{tabular}

$\mathrm{C}_{16: 0}$, Palmitic; $\mathrm{C}_{18: 0}$, Stearic; $\mathrm{C}_{20: 1}$, Arachidic; $\mathrm{C}_{18: 1}$, Oleic; $\mathrm{C}_{18: 2}$, Linoleic; $\mathrm{C}_{18: 3}$, Linolenic ; $\mathrm{C}_{20: 1, \text { Gadoleic. }}$

It can be seen from Table (1) that the fatty acids contents of wheat germ oil were $20.14 \%$ of saturated fatty acids and $79.86 \%$ of unsaturated fatty acids,
Stability of wheat germ oil:

Primary oxidation of oil: Primary oxidation was measured by peroxide value (PV) according to the method of (A.O.C.S.,1996).

Secondary oxidation of oil : Secondary products were measured by para-anisidine value $(p-A V)$ according to the method of (A.O.C.S.,1996).

Total oxidation of oil: The total oxidation was calculated as follows:

Total oxidation $=2$. $\mathrm{PV}+p-\mathrm{AV}$

Conjungated dienes and trienes: $A$ sample of about $200 \mathrm{mg}$ was dissolved in $100 \mathrm{ml} \mathrm{n}$-hexane and mixed thoroughly. The absorption was measured in the UV region using a Shimadzu UV-Visible 240 Recording Spectrophotometer (Tokyo, Japan) and the optical densities were measured at 233 and 268 $\mathrm{nm}$ for dienes and trienes, respectively. The percentages of conjugated acids were calculated according to the method of (A.O.C.S.,1996).

Color intensity: Oil samples were diluted with $n$ hexane at concentration of $1 \%$ oil solution. The solution was measured in the UV region using Shimadzu Recording Spectrophotometer (Tokyo, Japan) at wave length $430 \mathrm{~nm}$ as previously described by (Masayuki et al.,1985). Readings of an optical density (O.D) indicated the concentration of the coloring matter in the oil, i.e. color intensity.

Statistical analysis Samples of wheat germ oil were analyzed individually in triplicate, and the results were reported as mean $\pm S D$. Statistical significance of the differences between mean values was assessed by one-way ANOVA with SAS software (SAS,2004). Tukey multiple comparison procedure was used to compare the means. A probability to $p \leq$ 0.05 was used to establish the statistical significance.

\section{RESULTS AND DISCUSSION}

Fatty acids composition of wheat germ oil is recorded in Table (1). where the saturated : unsaturated ratio were 1:3.96 respectively.

Palmetic acid makes more than $80.0 \% \mathrm{f}$ the saturated fatty acids of wheat germ oil. While linoleic acid 
makes more than $62.0 \%$ of the unsaturated fatty acids of wheat germ oil. These results are in a good agreement with the previous results reported by Lancas et al.,1994, Michael et al. 2006, Michael and Nurhan 2007 and Yuldasheva et al. 2010.
Wheat germ oil characteristics during periodical storage are presented in table (2)

Table: 2 Wheat germ oil characteristics during periodical storage at $\left(25-30^{\circ} \mathrm{C}\right)$.

\begin{tabular}{|c|c|c|c|}
\hline Storage period/day & Acid value $(\mathrm{mg} / \mathrm{g})$ & $\begin{array}{c}\text { lodine value } \\
(\mathrm{g} / 100 \mathrm{~g})\end{array}$ & $\begin{array}{c}\text { Color intensity } \\
(430 \mathrm{~nm})\end{array}$ \\
\hline Control $^{*}$ & $14.88 \pm 0.19^{\mathrm{G}}$ & $127.10 \pm 1.59^{\mathrm{A}}$ & $0.207 \pm 0.003^{\mathrm{A}}$ \\
\hline 1 & $17.55 \pm 0.24^{\mathrm{F}}$ & $126.40 \pm 1.71^{\mathrm{A}}$ & $0.198 \pm 0.003^{\mathrm{B}}$ \\
\hline 2 & $18.31 \pm 0.23^{\mathrm{E}}$ & $124.60 \pm 1.56^{\mathrm{AB}}$ & $0.181 \pm 0.002^{\mathrm{C}}$ \\
\hline 3 & $19.56 \pm 0.26^{\mathrm{D}}$ & $122.90 \pm 1.66^{\mathrm{ABC}}$ & $0.170 \pm 0.002^{\mathrm{D}}$ \\
\hline 4 & $20.03 \pm 0.25^{\mathrm{D}}$ & $120.70 \pm 1.51^{\mathrm{BCD}}$ & $0.154 \pm 0.002^{\mathrm{E}}$ \\
\hline 5 & $21.74 \pm 0.29^{\mathrm{C}}$ & $119.10 \pm 1.61^{\mathrm{CD}}$ & $0.138 \pm 0.002^{\mathrm{C}}$ \\
\hline 6 & $22.60 \pm 0.30^{\mathrm{B}}$ & $118.40 \pm 1.60^{\mathrm{CD}}$ & $0.129 \pm 0.002^{\mathrm{G}}$ \\
\hline 7 & $23.46 \pm 0.32^{\mathrm{A}}$ & $117.20 \pm 1.58^{\mathrm{D}}$ & $0.120 \pm 0.002^{\mathrm{H}}$ \\
\hline
\end{tabular}

${ }^{*}$ Collected after milling and stored at $5^{\circ} \mathrm{C}$ until use

Values are presented as mean \pm SD of duplicate samples analyzed in triplicate.

The same capital litter in the same column indicates there is no significant difference.

The effect of periodical storages at temperature $\left(25^{\circ} \mathrm{C}-30^{\circ} \mathrm{C}\right)$ was studied. Of these properties acid value, iodine value and color determination at 430 $\mathrm{nm}$.

Concerning the acid value of the oil it was observed that there is a gradual increases of acidity from 17.55 $(\mathrm{mg} / \mathrm{g})$ to $23.46(\mathrm{mg} / \mathrm{g})$ after 7 days compared to control of $14.88(\mathrm{mg} / \mathrm{g})$. The iodine value decrease by time from $127.10(\mathrm{mg} / \mathrm{g})$ (control) to $117.20(\mathrm{mg} / \mathrm{g})$ after 7 days. The spectroscopic determination of optical density (color) of oil micella in $n$-hexan $(1 \%)$ is markety decreased from 0.207 to 0.120 after 7 days (Pomeranz,1980;Masayuki et al.,1985;Tong and Lawrence,2001). Increase of acid value is due to the action of enzyme during the storage period. lodine value decrease may attributed to the chemical conversion of the unsaturated bonds during the storage. The color pigments are affected by storage giving a gradual decrease in optical density of oil micella (Galliard,1981,1983;Pomeranz,1992).

Wheat germ oil stability during periodical storage is illustrated in Table (3)

Table: 3. Wheat germ oil stability during periodical storage at $\left(25-30^{\circ} \mathrm{C}\right)$.

\begin{tabular}{|c|c|c|c|}
\hline Storage period/day & Peroxide value $(\mathrm{mEq} / \mathrm{kg})$ & $p$-anisidine value & Total oxidation \\
\hline Control & $1.14 \pm 0.01^{\mathrm{H}}$ & $7.35 \pm 0.09^{\mathrm{F}}$ & $9.63 \pm 0.12^{\mathrm{H}}$ \\
\hline 1 & $1.71 \pm 0.02^{\mathrm{G}}$ & $7.54 \pm 0.10^{\mathrm{EF}}$ & $10.96 \pm 0.15^{\mathrm{G}}$ \\
\hline 2 & $3.70 \pm 0.05^{\mathrm{F}}$ & $7.66 \pm 0.10^{\mathrm{ED}}$ & $15.06 \pm 0.19^{\mathrm{F}}$ \\
\hline 3 & $7.40 \pm 0.10^{\mathrm{E}}$ & $7.83 \pm 0.11^{\mathrm{ED}}$ & $22.63 \pm 0.31^{\mathrm{E}}$ \\
\hline 4 & $9.09 \pm 0.11^{\mathrm{D}}$ & $7.89 \pm 0.10^{\mathrm{D}}$ & $26.07 \pm 0.33^{\mathrm{D}}$ \\
\hline 5 & $12.98 \pm 0.17^{\mathrm{C}}$ & $8.71 \pm 0.12^{\mathrm{C}}$ & $34.67 \pm 0.47^{\mathrm{C}}$ \\
\hline 6 & $15.58 \pm 0.21^{\mathrm{B}}$ & $9.30 \pm 0.13^{\mathrm{B}}$ & $40.46 \pm 0.55^{\mathrm{B}}$ \\
\hline 7 & $19.48 \pm 0.26^{\mathrm{A}}$ & $9.64 \pm 0.13^{\mathrm{A}}$ & $48.60 \pm 0.66^{\mathrm{A}}$ \\
\hline
\end{tabular}

Values are presented as mean \pm SD of duplicate samples analyzed in triplicate.

The same capital litter in the same column indicates there is no significant difference. 
Stability of wheat germ oil is determined by certain parameters namely $P$-anaidine, peroxide value with the calculated total oxidation. $P$-anisidine is explicit by secondary oxidation of the unsaturated compound. In the contrary, peroxide value reflexes the progress of primary oxidation in which peroxide are formed at different rate. The parameter oxidation is forward by secondary oxidation as determined by $P$-anisidine value.
The calculated total oxidation (2.P.V + P-AV) shows that oxidation is very high (48.60) after 7 days compared to that of control (9.63) (Galliard,1981,1983).

Influence of periodical storage on the formation of conjugated dienes and trienes is shown in Table (4) .

Table 4. Influence of periodical storage at $\left(25-30^{\circ} \mathrm{C}\right)$ on the formation of conjugated dienes and trienes .

\begin{tabular}{|c|c|c|c|}
\hline \multirow{2}{*}{ Storage period/day } & \multicolumn{3}{|c|}{ Conjugation } \\
\cline { 2 - 4 } & Diene $(234 \mathrm{~nm})$ & Triene $(268 \mathrm{~nm})$ & Total conjugation \\
\hline Control & $4.76 \pm 0.06^{\mathrm{G}}$ & $0.84 \pm 0.01^{\mathrm{H}}$ & $5.60 \pm 0.07^{\mathrm{H}}$ \\
\hline 1 & $5.52 \pm 0.07^{\mathrm{F}}$ & $1.00 \pm 0.01^{\mathrm{G}}$ & $6.52 \pm 0.09^{\mathrm{G}}$ \\
\hline 2 & $6.60 \pm 0.08^{\mathrm{E}}$ & $1.22 \pm 0.01^{\mathrm{F}}$ & $6.88 \pm 0.10^{\mathrm{F}}$ \\
\hline 3 & $7.28 \pm 0.10^{\mathrm{C}}$ & $1.41 \pm 0.02^{\mathrm{E}}$ & $8.69 \pm 0.12^{\mathrm{E}}$ \\
\hline 4 & $7.79 \pm 0.10^{\mathrm{C}}$ & $1.51 \pm 0.02^{\mathrm{D}}$ & $9.30 \pm 0.12^{\mathrm{D}}$ \\
\hline 5 & $8.50 \pm 0.11^{\mathrm{C}}$ & $1.74 \pm 0.02^{\mathrm{C}}$ & $10.24 \pm 0.14^{\mathrm{C}}$ \\
\hline 6 & $8.79 \pm 0.12^{\mathrm{A}}$ & $2.02 \pm 0.02^{\mathrm{B}}$ & $10.81 \pm 0.14^{\mathrm{B}}$ \\
\hline 7 & $9.03 \pm 0.12^{\mathrm{A}}$ & $2.34 \pm 0.03^{\mathrm{A}}$ & $11.37 \pm 0.15^{\mathrm{A}}$ \\
\hline
\end{tabular}

Values are presented as mean \pm SD of duplicate samples analyzed in triplicate.

The same capital litter in the same column indicates there is no significant difference .

Conjugated dienes and trienes determined spectrophotometery showed that the double bonds in linolein and linolenic acids are rearranged to give 1-4 U.V. absorbance at 234 and $268 \mathrm{~nm}$ respectively. Concerning total conjugation it can be seen that there is increase in value by time simillary to total oxidation of the oil (Galliard,1981,1983;Pomeranz,1992).

Course of lipase inhibition in wheat germ during periodical exposure at constant temperature $\left(70^{\circ} \mathrm{C}\right)$ is presented in Table (5).

Table: 5. Course of lipase inhibition in wheat germ during periodical exposure at constant temperature $\left(70^{\circ} \mathrm{C}\right)$.

\begin{tabular}{|c|c|}
\hline Temperature $\left(70^{\circ} \mathrm{c}\right) / \mathrm{min}$ & Acid value $\mathrm{mg} / \mathrm{g}$ \\
\hline Control & $14.88 \pm 0.19^{\mathrm{A}}$ \\
\hline 15 & $14.30 \pm 0.19^{\mathrm{B}}$ \\
\hline 30 & $12.59 \pm 0.16^{\mathrm{C}}$ \\
\hline 60 & $12.02 \pm 0.16^{\mathrm{D}}$ \\
\hline
\end{tabular}

Values are presented as mean \pm SD of duplicate samples analyzed in triplicate.

The same capital litter in the same column indicates there is no significant difference.
Thus exposing the wheat germ to temperature with shorts heating time will sufficiency inactivate the lipase (Devin and Oscar,2006). Heat treatment at $70^{\circ} \mathrm{C}$ for different period 15,30 and $60 \mathrm{~min}$. were treated to carry out the course of lipase inhibition.

At control experiment the acid value amount to 14.88 $\mathrm{mg} / \mathrm{g}$ whereas after $15 \mathrm{~min}$ it reaches similar value of $14.30 \mathrm{mg} / \mathrm{g}$. After $30 \mathrm{~min}$, the acidity decrease to $12.59 \mathrm{mg} / \mathrm{g}$, whereas it reached 12.02 after $60 \mathrm{~min}$ heating. It seam that $30 \mathrm{~min}$ is advantageous to stop the lipase activity to areasnable level and to keep the rest of oil in the form of triglyceride. The lipase enzyme converts the triglyceride into diglyceride unsabcequantly into monoglyceride with liberating free fatty acids (Galliard,1981, 1983; Stauffer, 1987; O'connor et al.,1992;Fadilogu and Soylemez,1996).

\section{CONCLUSION}

- Application of statistical analysis reveals that the samples were analyzed and the results include SD and statistical significant with the help of ANOVA.

- Wheat germ oil contains mono-unsaturated and poly-unsaturated fatty acids in different 
amounts. The higher percentages of the linoleic and the presence of reasonable amounts of oleic and linolenic makes the oil sensitive to oxidation.

- In case of storage of oil the acid value of oil, it was observed that there is a gradual increase of acidity till it reaches a maximum of $23.46(\mathrm{mg} / \mathrm{g})$ compared to initial value of $14.88(\mathrm{mg} / \mathrm{g})$.

- $\quad$ The color intensity during storage at $430 \mathrm{~nm}$ and iodine value, meanwhile are affected by storage giving rise to a lower values of iodine value as well as color intensity.

- The calculated total oxidation shows marked increase by time indicating the conversion of unsaturated system prior to oxidation into hydroperoxide.

- With difference to the stability of wheat germ oil during storage, the oil is prone to higher primary oxidation (hydroperoxide formation) and subsequently to lower secondary oxidation (1-4 alkadienal formation). Thus, total oxidation reached higher values at the end of storage period.

- $\quad$ Studying the lipase inhibition at $70^{\circ} \mathrm{C}$ during periods of 15,30 and 60 min., it was found that the fatty acid liberated at different periods decreased from $14.88 \quad(\mathrm{mg} / \mathrm{g})$ (control) to acid value of $12.02(\mathrm{mg} / \mathrm{g})$ after $60 \mathrm{~min}$. It seems that the acid value after 30 $\min$. at $70^{\circ} \mathrm{C}$ is suitable value to suppress the activity of enzyme.

\section{ACKNOWLEDGEMENT}

Thanks are acknowledged to Prof. Dr. M. Hassan ElMallah for this criticism and valuable discussions.

\section{REFERENCES}

A.O.C.S. (1996) The Official and Tentative Methods of the American Oil Chemist's Society, 3rd Ed. American Oil Chemist's Society, 508 South Sixth Street, Champaign, Illinois.

Appett G. (1986) Nutritional value and stability of extruded wheat germproduct.Getreid Mehl Brot 40:176-180.

Devin J. Rose and Oscar A. Pike (2006). A simple method to measure lipase activity in wheat and wheat bran as an estimation of storage quality. J. Am Oil Chem. Soc. 83: 415-419.

Fadilogu, S., and Z. Soylemez (1996). Preliminary kinetic sludies on the esteratic and lipolytic components of a commercial wheat germ lipase. J. Agric. Food Chem. 44: 3015-3017.
Galliard, T. (1980). Degradation of acyl lipids: Hydrolytic and oxidative enzymes in The Biochemistry of Plants. Lipids: Structure and Function, edited by P.K. Stumpt and E.E.Conn, Academic Press, New York, Vol. 4, pp. 85-116.

Galliard, T. (1983). Enzymatic degradation of cereal lipids, in Lipids in Cereal Technology, edited by P.J. Barnes. Academic Press. New York, pp. 11-147.

Galliard, T., and D.M. Gallagher (1988). The effect of wheat bran particle size and storage period on bran flavour and baking quality of bran/flour blends. J. Cereal Sci. 8: 147-154.

International Union of Pure and Applied Chemistry (IUPAC) (1987) Standard Methods for the Analysis of Oils and Fats and Derivativs, 7th revised and enlarged edn., edited by C. Raquot and A. Hautfenne, Blackwell Scientific, London.

Kahlon, T.S. (1989) Nutritional implication and uses of wheat and oat kernel oil. Cereal Foods world 34: 872875.

Lancas, F.M.; M.E.C. Queiroz and I.C.E. da Silva (1994) Seed oil extraction with supercritical carbon dioxide modified with pentane. J. Chromatographia, 39:687692.

Lehtinen, P.,K. Kiiliainen, I. Lehtomaki, and S. Laakso (2003). Effect of heat treatment on lipid stability in processed oats. J. Ceereal Sci. 37:215-221.

Masayuki Taniguchi, Toshifumi Tsun, Masahito Shibata and Takeshi Kobayashi (1985) Extraction of oils from wheat germ with supercritical carbon dioxide. Agric. Biol. Chem, 49: 2367-2372.

Michael Eisenmenger, Nurhan T. Dunford, Fred Eller, Scott Taylor, and Jose Martinez (2006). Pilot-scale supercritical carbon dioxide extraction and fractionation of wheat germ oil. J. Am Oil Chem. Soc. 83:863-868.

Michael Eisemmenger and Nurhan Turgut Dunford (2007) Bioactive components of commercial and supercritical carbon dioxide processed wheat germ oil. J. Am Oil Chem. Soc. 85:55-61.

Mitruk, B.N. (1984) Gas Chromatographic Applications in Microbiology and Medicine, John Wiley and Sons, Inc., New York.

Mukherjee, K.D., and M.J. Hills (1994). Lipase from plants, in Lipases: Their Structure, Biochemistry, and Application, edited by P. Wooley and S.B. Petersen, University Press, Cambridge, pp. 49-75.

O'connor, J.H.J. Perry, and J.L. Harwood (1992). A Comparison of lipase activity in various cereal grains. J. Cereal Sci., 16:153-163.

Pomeranz, Y. (1980) Composition and functionality of wheat flour components, in Wheat Chemistry and 
Technology, 3rd edn., edited by Y.Pomeranz, American Association of Cereal Chemists, St. Paul, MN, Vol. 2. pp. 219-370.

Pomeranz, Y. (1992) Biochemical, functional, and nutritive changes during storage, in Storage of Cereal Grains and Their Products, 4th edn., edited by D.B. Sourcer, American Assoication of Cereal Chemists, St. Paul, MN, pp.55-141.

SAS (2004) Statistical Analysis System. SAS User's Statistical SAS Institute Inc. Editors, Cary, NC.

Sonntage, N.O.V. (1979) Composition and characteristics of individual fats and oils, in Bailey's Industrial Oil and Fat Products, Vol. 1,4 ${ }^{\text {th }}$ edn., edited by D. Swern, John Wiley \& Sons, New York, pp. 289-477.
Stauffer, C.E. (1987). Ester hydrolases, in Enzymes and Their Role in Cereal Technology, edited by J.E. kruger, D. Lineback, and C.E. Stauffer. American Association of Cereal Chemistry, St. Paul, MN, pp. 265-280.

Tong Wang and Lawrence A .Johnson (2001). Refining high-free fatty acid wheat germ oil. J. Am Oil Chem. Soc. 78:71-76.

Vetrimant, R., and P. Haridas Rao (1990). Studies on stabilization of wheat bran. J. Food Sci. Technol. Mysore 27:332-335.

Yuldasheva, N.K.; Ul'chenko, and Glushenkova, A.I. (2010) Wheat germ oil. J. Chemistry of Nautral Compounds, 46:97-98. 